Book Review

\title{
Trying Leviathan: The Nineteenth-Century New York Court Case that Put the Whale and Challenged the Order of Nature
}

D. Graham Burnett. 2007. Princeton University Press. Pp. 304 color plates, halftones, bibliography, index. \$29.95 (cloth). ISBN 9780691129501.

\author{
Reviewed by E. N. Anderson ${ }^{1}$ \\ Reviewer Address: ${ }^{1}$ Department of Anthropology, University of California, Riverside, Riverside, California 92521
}

Received: January 2009

Published: August $3^{\text {rd }} 2010$
Volume 1:4-6

(C) 2010 Society of Ethnobiology
My fishermen friends in old Hong Kong regarded whales and porpoises as anomalous. These creatures were outwardly fish, but inwardly and behaviorally like mammals. Thus they were sacred and taboo, like other anomalous fish. No one would hunt them, and if they were killed accidentally they had to be offered to the fishers' protective goddess.

It seems that whales were equally anomalousBurnett even uses the word-in old New York. Having written one of the very few books on folk taxonomy of fishes (Anderson 1973), I could not resist this history. Starting with the title-recall that "trying" refers to both court action and boiling oil out of a whale-the book is witty, well-written, concise, and delightful. Historians, unlike anthropologists, are still supposed to write well, and we are herein spared such words as "neoliberalism" and "globalization"— vapid terms whose sole function is to show off multisyllabic jargon.

It relates the story of a trial in New York City in 1818. One Samuel Judd, dealer in whale oil, tried to get around a new law for inspecting fish oil, and thus avoid paying a hefty fee, by claiming that whales are not fish. The inspector (for the State of New York) promptly took him to court. The defense called the great ichthyologist and naturalist Samuel Mitchill (well known to any modern ichthyologist for his classic descriptions of fish species). Mitchill testified according to the latest science, from Linnaeus and Cuvier: whales are mammals, not fish. The fiery and charismatic lawyer William Sampson argued for the plaintiff, and brought in countless people to testify that almost everyone knew a whale was a fish. The only whaler the defense could bring was a captain with the incredible cognomen of Preserved Fish, "whose name, predictably, attracted the mirth of several commentators" (p. 95; Preserved, pronounced preserv-ed, was a fairly common name among New England Puritans).

Judd's case was not helped by the fact that he was obviously trying to cheat the state rather than teach zoology. Yet, "original intent" was as messy then as now. The law was new, so the people who framed it could actually be brought in to testify. Gideon Lee, who first advocated it, made it clear that he had meant it to include all fish, whales included. Lee was a tanner; tanners used much fish oil (not usually whale oil) in working hides. So the direct court battle was really between whale oil sellers and fish oil buyers. Peter Sharpe, the legislator who actually got it passed, had understood differently - he wanted a law that covered fish oil in the narrow sense, not whale oil.

Sampson argued a populist line, setting the ordinary people against the ivory-tower scholar, and New Yorkers (who generally used "fish" for any sea creature) against New Englanders (who tended to separate "whales," so important a quarry there). This proved successful, and the jury took only 15 minutes to find that, for purposes of the law, a whale was a fish. Sharpe subsequently rewrote the law to make it clearer and thus to exempt whale oil. The matter stayed so poorly resolved that there was another trial, involving meat, not oil, but otherwise the same story, in 1919!

Today, especially after the shenanigans of the Bush administration, this may sound like yet another American triumph of obscurantism and antiintellectualism over science. Yet, in Mitchill's day, the idea that whales were mammals and not fish was new, and it was far from obvious. Darwin's revelation of what made real natural relationships was far in the future. There was no obvious reason to look at milk, live birth, lungs, and a horizontal tail (Mitchill's main 
points of emphasis) rather than aquatic habitat, streamlined body shape, fins instead of legs, hairless skins, and active swimming and diving (see esp. pp. 8182). Thank goodness the court was not aware of obligatory air-breathing lungfish. They knew of the "duck-billed beaver" (platypus) but were mercifully unaware that it lays eggs. They did know that Linnaeus had classed "men" with monkeys (in the Primates), and were properly scandalized, using the same language later used to attack Darwin. This did not help Mitchill's case.

Sampson made much of the contrast between mere academic anatomy and actual functional similarities. Folk usage was based on the latter. It, and therefore the obvious intent of the law as far as its original sponsors was concerned, was perfectly clear. Even today, the English language maintains "shellfish," "cuttlefish," and so on, talks of the "whale fishery," and even continues to refer to several small whales (notably Globicephala spp.) as "blackfish"!

Burnett is aware, also, that Darwinian thinking is not too kind to the category "whale." The English word is paraphyletic. It includes the giant baleen whales, but also the sperm whale, killer whale, and other toothed whales that are actually overgrown dolphins. The English word "fish" is also paraphyletic, and really messy. A whale is actually closer to a trout than the latter is to a hagfish or even a shark. We may also remember, going back to the platypus, that the category "mammal" is still up for grabs too. The platypus is classed as a mammal, but is actually more like a surviving mammal-like reptile.

Burnett sees the case as "an occasion to investigate cetaceans as 'problems of knowledge...'; a window onto the contested terrain of zoological classification...; and...an opportunity to assess the broader place of natural history... in New York and in the United States...in the early nineteenth century" (p. 190). Actually, he does more. He deals with the whole question of folk classification, and the similarities and differences between it and scientific taxonomy.

Among the similarities are the obvious influences of "common sense," economics, and utility. Burnett has not read much anthropology, and is thus apparently unaware that "fish" is a universal form-class in human languages, and almost everywhere includes whales. But he unpacks the many "common sense" uses of the term in American English of the time, and makes some very astute remarks about classification. Among them is a long essay on the special advantages of folk classification, based as it is on intimate working knowledge of living creatures. Quoting one Susan Scott Parrish, he refers to working people's "local, experimentally derived, and multiracial epistemologies" (p. 103). "Multiracial" is offensive here, implying that knowledge and intelligence are genetically coded and racially different, but evidently "multicultural" is meant.

Thus, knowledge is created through work. Some kinds of knowledge are created by the work of whaling; others by the work of cutting up specimens in a comparative anatomy lab. Some kinds are created by merchants selling and buying oil, others by lawyers marshalling and deploying shaky information in a courtroom. We see here the government responding (rather lamely) to folk and scientific usages, the people trying to sort it all out, and the final triumph of folk sense over learned controversy. Knowledge is negotiated, and largely in terms of how it can be used in actual everyday real-world undertakings.

This strongly supports the "utilitarian" tradition in ethnobiology, but gives some comfort to the "Platonic" trend and the "social constructionist" trend also. People clearly form abstract ideas-schemas-from what they learn by interactive work. They then often use said schemas in governing, status-jockeying, social gaming, and other wider (and often shadier) pursuits. It seems to me that the utilitarian, or rather interactivepragmatic, trend is the basic one, at least in this case. Thanks to all these concerns, the book is a wonderful one for showing how important the whole issue is. If anyone is still deluded by the claim that folk classification is "trivial," this book emphatically proves otherwise.

Debates about "fish" continued for decades. Herman Melville opted for "fish" in Moby Dick (allowing Burnett to bring torrid romantic emotionality into the book, by going into Melville in detail). The great William Whewell, who coined the word "scientist," knew of the Judd trial, and was moved to consider the taxonomic issues it raised. Whewell saw types in a Platonic way: induced as Ideas. John Stewart Mill then crossed swords with Whewell, seeing taxa as defined by people according to use, rather than being inherent (God-given?) in nature (Burnett, pp. 215ff). This fundamental debate is still with us. I am thus glad to learn of the Judd trial and its role in starting it.

Finally, Burnett follows an important trend in history by seeing much importance in what we forget. The very real questions of when a whale is a fish, and of how social is science, are not salient to most people, however much they are to us ethnobiologists. We try 
to situate and contextualize the knowledge we record, showing how it fits with wider social and cultural practices. Others have not been so aware, and thus tend to erase stories that reveal the case for whales as fish or the role of legal pettifogging in scientific definitions. I can do no better than echo his final words (p. 220): "Is a whale a fish? Is science social? Is philosophy historical? The precedent question is always this: What stories must be forgotten to answer these questions?" 